\title{
THE INFLUENCE OF HEAVY METAL IONS, SPERMINE AND SODIUM NITROPRUSSIDE ON ATP-HYDROLASES OF CELL MEMBRANES OF RAT COLON SMOOTH MUSCLE
}

\author{
A. A. KAPLIA
}

Palladin Institute of Biochemistry, National Academy of Sciences of Ukraine, Kyiv;
e-mail: kaplya@biochem.kiev.ua

The specific features of functional lability of the rat colon smooth muscle (CSM) ATP-hydrolases were studied. $\mathrm{Na}^{+}, \mathrm{K}^{+}$-ATPase activity is effectively inhibited by divalent ions of both transition $(\geq 0,1 \mu \mathrm{M})$ and nontransition $(\geq 1 \mu \mathrm{M})$ heavy metals in succession by efficiency: $\mathrm{Cu}^{2+}>\mathrm{Fe}^{2+} \geq \mathrm{Cd}^{2+}(10 \mu \mathrm{M})$. Polyamine spermine $(0,5-1,0 \mathrm{mM})$ is a weak $\mathrm{Na}^{+}, \mathrm{K}^{+}$-ATPase inhibitor at saturation concentrations of ions and substrate. Sodium nitroprusside $(1 \mathrm{mM})$ as nitric oxide-generating compound exhibits weak $\mathrm{Na}^{+}, \mathrm{K}^{+}$-ATPase inhibition only after prolonged preincubation with membranes. $\mathrm{Mg}^{2+}-A T P$-hydrolase activity in all cases is much more resistant to studied agents. Considering the example of the CSM Na+ $\mathrm{K}^{+}$-ATPase it is assumed that enzyme has specific biochemical features that contribute to its role as a potential target and redox-sensor, mediating the pathological mechanisms of heavy metal intoxication and cell oxidative damage.

Key words: ATP-hydrolases, $\mathrm{Na}^{+}, \mathrm{K}^{+}$-ATPase, colonic smooth muscle, heavy metals, spermine, sodium nitroprusside.

$\mathrm{N}$ $\mathrm{a}^{+}, \mathrm{K}^{+}$-ATPase (EC 3.6.1.37) is a fundamental enzyme of the ion homeostasis regulation by providing energy-dependent electrogenic contradirectional transport of $\mathrm{Na}^{+}$and $\mathrm{K}^{+}$ across plasma membrane of animal cells to maintain electrochemical gradient of monovalent ions, membrane potential, electrical excitability and associated processes of transport of ions and metabolites [1]. $\mathrm{Na}^{+}, \mathrm{K}^{+}$-ATPase via $\mathrm{Na}^{+} / \mathrm{Ca}^{2+}$ exchanger is also involved in the control of calcium homeostasis and electromechanical coupling in smooth muscle cells $[2,3]$. Being the main consumer of the ATP energy, synthesis of which requires $20-80 \%$ of the oxygen consumed by mammalian cell, $\mathrm{Na}^{+}, \mathrm{K}^{+}$-ATPase is believed to be involved into pathophysiological responses under oxidative stress, ischemia-hypoxia, mitochondrial dysfunction, reprogramming of the oxidative metabolism pathways, etc [4-6]. Labile enzymatic SH-groups are known to be the targets of oxidative modification by products of the interaction of the superoxide $\left(\mathrm{O}_{2}{ }^{-}\right)$, produced by plasma membrane NADPH oxidase or mitochondrial electron transport chain complexes, and nitric oxide (NO) with peroxynitrite $\left(\mathrm{ONOO}^{-}\right)$formation, $\mathrm{O}_{2}^{--}$dismutation to hydrogen peroxide $\left(\mathrm{H}_{2} \mathrm{O}_{2}\right)$ and/or further generation of hydroxyl radical $\left(\mathrm{OH}^{\circ}\right)$ in Haber-Weiss reaction, catalyzed by transition metals $[7,8]$.
Chronic iron overload disorders (hemochromatosis, chronic drug or dietary intoxication) can be an aggravating factor of the pathogenesis, associated with accumulation of extremely toxic iron pool not linked to transferrin or ferritin in the plasma or inside the cell, respectively. It may cause the redox imbalance in tissues and entail cellular damage both at plasma membrane level and intracellularly. Toxic action of other heavy metals depends on mutual saturation and interactions [8-12]. Protein-free iron is also present in miscellaneous diseases primarily developed without iron overloaded conditions [10]. $\mathrm{Na}^{+}, \mathrm{K}^{+}$-ATPase along with respiratory chain enzymes may be the main targets of the toxic action of non-transferrin-bound iron, for example, in cardiomyocytes [9].

On the other hand, the dysperistalsis in inflammatory and ischemic large bowel diseases, colitis, tumor growth, that are accompanied by increase of cellular damaging factors such as reactive oxygen or nitrogen species, disorder of the epithelial barrier function and, finally, sarcolemmal defect, ultimately can be a result of impairment of the electromechanical coupling in smooth muscle. However, the functional features of the colonic smooth muscle (CSM) $\mathrm{Na}^{+}, \mathrm{K}^{+}$-ATPase are actually unexplored. It is important to ascertain the biochemical properties of 
this enzyme in comparison with ATP-hydrolases not belonging to P-type family to evaluate the expected sarcolemmal targets participating in impairment of the smooth muscle motility of this intestine region.

It was shown earlier that $\mathrm{Na}^{+}, \mathrm{K}^{+}$-ATPase in the membrane preparations of rat CSM is represented by prevailing catalytic subunit $\alpha 1$-isoform bearing the rodent specific resistance to cardiac glycosides, i. e. being inhibited by millimolar but not micromolar ouabain concentrations [13]. As follows from our previous data CSM Na+ $\mathrm{K}^{+}$-ATPase is characterized by low sensitivity to hydrogen peroxide, but in the presence of micromolar $\mathrm{Fe}^{2+}$ concentrations is inhibited in physiological (nanomolar) range of $\mathrm{H}_{2} \mathrm{O}_{2}$ evidently due to hydroxyl radical production [14]. Considering that $\mathrm{Na}^{+} \mathrm{K}^{+}$-ATPase activity is used as analytical tool for determination of the potential toxicity of a number of compounds of different nature [11], the appeared enhancement of the CSM $\mathrm{Na}^{+}, \mathrm{K}^{+}$-ATPase sensitivity to $\mathrm{H}_{2} \mathrm{O}_{2}$ in the absence of EGTA may serve as sensitive and reliable test for the presence of the transition metals contaminants in the medium [14]. Contrary to $\mathrm{Na}^{+}, \mathrm{K}^{+}$-ATPase, the greater resistance to oxidation of $\mathrm{Mg}^{2+}$-ATP-hydrolase corresponds to differences in functional importance of SH-groups in these enzyme types [14]. It is also important to evaluate CSM Na${ }^{+}, \mathrm{K}^{+}$-ATPase inhibitory pattern for other compounds with different effector groups and action mechanisms.

The aim of this study is to comparatively examine the sensitivity of the ATP-hydrolases (namely $\mathrm{Na}^{+}, \mathrm{K}^{+}$-ATPase and $\mathrm{Mg}^{2+}$-ATPase) of rat CSM cellular membranes to divalent transition and nontransition metal ions and to evaluate the inhibitory potency of polyamine spermine and nitric oxidegenerating compound sodium nitroprusside for these enzymatic systems.

\section{Materials and Methods}

The isolation of the nonmitochondrial membrane fraction from rat CSM, protein and ATPase activity determination after unmasking procedure by digitonin pretreatment of the membranes were carried out in accordance with the previously described methodical conditions [14]. Male Wistar rats were fed with the standard diet of the vivarium and deprived of food the day before experiment. Animals were anesthetized by diethyl ether inhalation and decapitated. The experiments were done in accordance with guidelines for keeping and work with laboratory animals laid down in the European Conven- tion for the Protection of Vertebrate Animals used for Experimental and Other Scientific Purposes (Strasbourg, 1986). To estimate the effect of divalent heavy metals $\left(0.1-10.0 \mu \mathrm{M} \mathrm{FeSO}_{4}, \mathrm{CuSO}_{4}\right.$ or $\left.\mathrm{CdCl}_{2}\right)$ the digitonin-permeabilized membranes were preincubated for $30 \mathrm{~min}$ at $37{ }^{\circ} \mathrm{C}$ in the ATP- and EGTAfree medium. ATPase reaction was started by simultaneous addition of $3 \mathrm{mM}$ ATP and $1 \mathrm{mM}$ EGTA mixture (final concentrations) [14]. To evaluate the spermine effect $(0.1-1.0 \mathrm{mM})$ this polyamine was added directly into the ATPase reaction mixture, but sodium nitroprusside action $(1 \mathrm{mM})$ was determined after membrane preincubation with this agent at $37{ }^{\circ} \mathrm{C}$ for different time intervals in the ATPase reaction medium in the presence of $1 \mathrm{mM}$ EGTA with subsequent addition of $3 \mathrm{mM}$ ATP to start the ATPase reaction. Concrete concentration and preincubation time range are given in figure captions. Corresponding enzymatic activity in membranes treated under the same conditions but without effector was taken as $100 \%$. Summarizing briefly, basic principles of methodological procedure are defined by standard characteristics and precautions of the detergent use in membranological studies. The mild detergent pretreatment of membranes at room temperature precedes the incubation with effector and/ or the enzymatic reaction (at $37^{\circ} \mathrm{C}$ ). It provides the possibility to set a moderate detergent concentration in accordance with the protein concentration of the membranes (1/1 ratio), necessary for permeabilization of the vesicles, but not for the full membrane solubilization. Following addition of the aliquots into the incubation medium at $37^{\circ} \mathrm{C}$ leads to a drastic decrease in the detergent concentration to ineffective, much lower than critical micelle concentration, preventing the distortion of the experimental results due to deleterious or the combined effect of detergent and membrane-acting compound. Possible interactions of effector with ligands and targets are also taken into account in such experimental conditions. Agents in used concentrations did not affect the color intensity by Chen (phosphomolybdate formation in the presence of ascorbate) [15], did not change the intensity of the spontaneous ATP hydrolysis and did not cause turbidity when using solubilizing concentrations of Ds-Na to stop the reaction.

Statistical analysis of the results was performed using Microsoft Office Excell 2007. The data are given as means \pm SEM, $n$ - number of used preparations. The significance of statistical differences between two groups was evaluated using Student's $t$-test $(P<0.05)$. 


\section{Results and Discussion}

It was shown that divalent heavy metal ions, regardless of whether they are transition metals in the reduced $\left(\mathrm{Fe}^{2+}\right)$ or oxidized form $\left(\mathrm{Cu}^{2+}\right)$, or nontransition metals $\left(\mathrm{Cd}^{2+}\right)$ and despite their ability to induce peroxidation processes, efficiently inhibited $\mathrm{Na}^{+}, \mathrm{K}^{+}$ATPase activity (Fig. 1, $A$ ). The enzyme sensitivity to transition metals appeared from submicromolar concentrations and was practically equal for divalent ions of iron and copper at 0.1 and $1.0 \mu \mathrm{M}$, respectively. $\mathrm{Cd}^{2+}$ inhibited only in the micromolar range, but to a lesser extent than transition metals. At $10 \mu \mathrm{m}$ $\mathrm{Cd}^{2+}$ the $\mathrm{Na}^{+}, \mathrm{K}^{+}$-ATPase activity decreased by $44 \%$. Copper ions are most potent at this concentration inhibiting enzymatic activity by $90 \%$. Hence, the ions are arranged in the order by inhibitory potency: $\mathrm{Cu}^{2+}$ $>\mathrm{Fe}^{2+} \geq \mathrm{Cd}^{2+}$.

It is generally accepted that inhibition by heavy metals is determined by a selective affinity to SH-, $\mathrm{NH}_{2}$ - and $\mathrm{COOH}$-groups, but most of toxic effects are caused by interaction with sulfhydryl groups [11]. While the effect of the transition metals is obviously associated with both their interaction with functionally important groups of the enzyme along with lipid peroxidation processes, the cadmium influence is only due to the interaction with functional groups $[12,14,16]$.

CSM $\mathrm{Mg}^{2+}$-ATPase is significantly more resistant to the inhibition by heavy metals and in the case of cadmium ions is almost insensitive at studied concentrations (Fig. 1, B). Primarily it corresponds to lower importance of the sulfhydryl groups for the function of this enzymatic system in comparison with $\mathrm{Na}^{+}, \mathrm{K}^{+}$-ATPase in CSM [14].

The numerous high-affinity specific binding sites distinct for $\mathrm{Fe}^{2+}$ and $\mathrm{Cu}^{2+}$ were detected on $\mathrm{Na}^{+}, \mathrm{K}^{+}$-ATPase subunits [17-19]. Adding hydrogen peroxide and ascorbate (i.e. conditions of intense generation of the hydroxyl radical) results in metalcatalyzed site-specific polypeptide cleavage into the distinct multiple fragments. Such highly reproducible cleavage of peptide bonds selectively catalyzed by submicromolar concentrations of iron or copper is sensitive to conformational state and used to study spatial organization of the $\mathrm{Na}^{+}, \mathrm{K}^{+}$-ATPase molecule and intramolecular conformational transitions [1719]. Our previous finding clearly showed [14] that kidney (exclusively $\alpha 1$-isozyme) and $\mathrm{CSM} \mathrm{Na}{ }^{+}, \mathrm{K}^{+}-$ ATPase inactivation in nanomolar range of $\mathrm{H}_{2} \mathrm{O}_{2}$ occurred only in the presence of iron ions and increased at $\mathrm{Fe}^{2+}$ micromolar range compared to inhi- bition resistance to hydrogen peroxide alone up to submillimolar concentrations (in EGTA presence). Revealed $\mathrm{Na}^{+}, \mathrm{K}^{+}$-ATPase hypersensitivity to $\mathrm{H}_{2} \mathrm{O}_{2}$ may serve as a reliable and sensetive test for the contaminations of transition heavy metals in the reaction mixture [14]. In the presence of ATP the highaffinity ATP-Met ${ }^{2+}$ complex is formed and cleavage sites are localized within active site of enzyme [20]. To prevent such phenomenon the ATPase reaction was run under EGTA chelation after enzyme preincubation with divalent ions.

Thus, it is likely that binding of heavy metals to $\mathrm{Na}^{+}, \mathrm{K}^{+}$-ATPase molecule modifies specific functional groups and separately from lipid peroxidation leads to conformational changes that affects functionally determinated $\mathrm{Na}^{+}, \mathrm{K}^{+}$-ATPase conformational mobility during the catalytic cycle. This may account for the effect of $\mathrm{Cd}^{2+}$. It is well-known that this heavy metal is extremely toxic for organism, it influences on membrane and cellular levels [12]. According to the obtained data its effect is specific for $\mathrm{Na}^{+}, \mathrm{K}^{+}$-ATPase as compared with $\mathrm{Mg}^{2+}$-ATPhydrolase in CSM (Fig. 1). It should be emphasized that the mechanism of $\mathrm{Na}^{+}, \mathrm{K}^{+}$-activated, $\mathrm{Mg}^{2+}$-dependent ATP hydrolysis fundamentally depends on the enzyme native conformation, essential for cyclic conformational turnover in the membrane and cation occlusion/deocclusion [1]. So, CSM $\mathrm{Mg}^{2+}$-ATPhydrolase is resistant to destabilizing effect of transition and nontransition heavy metals and can be the criterion of the membrane enzymatic resistance in comparative analysis. The data correspond to the results obtained for brain enzymes [11,21], specifying the common structural and functional differences, existing between the examined ATP-hydrolase families.

The diverse inhibitors were used for further study. Evaluating the spermine effect, it was shown that this polyamine at concentrations of $0.5-1.0 \mathrm{~mm}$ in the ATPase incubation medium in the presence of saturating concentrations of essential ions and ligands $\left(\mathrm{Na}^{+}, \mathrm{K}^{+}, \mathrm{Mg}^{2+}\right.$ and ATP) is a weak inhibitor of SMS $\mathrm{Na}^{+}, \mathrm{K}^{+}$-ATPase (Fig. 2). $\mathrm{Mg}^{2+}$-ATP-hydrolase appeared to be stable to this polyamine. The obtained data for CSM enzymes are in accordance with other investigations in different tissues. Polyamines are considered as $\mathrm{Na}^{+}, \mathrm{K}^{+}$-ATPase inhibitors that exhibit complex interactions with ions and the substrate depending on different conformational states during enzyme catalytic turnover $[22,23]$. Lack of the effect on $\mathrm{Mg}^{2+}$-dependent hydrolysis of ATP compared 
$A$

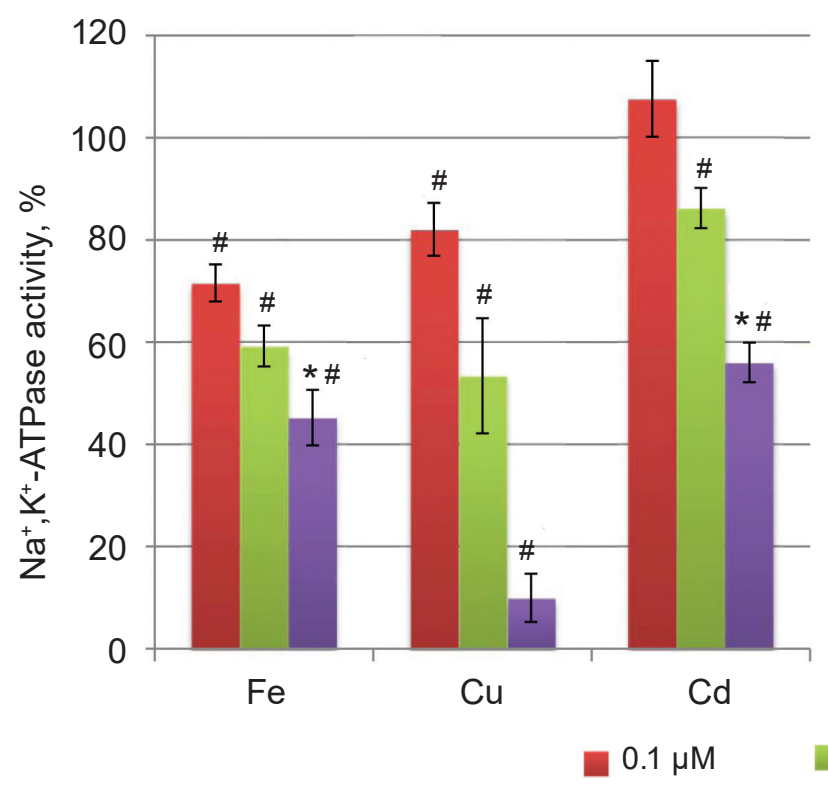

$B$

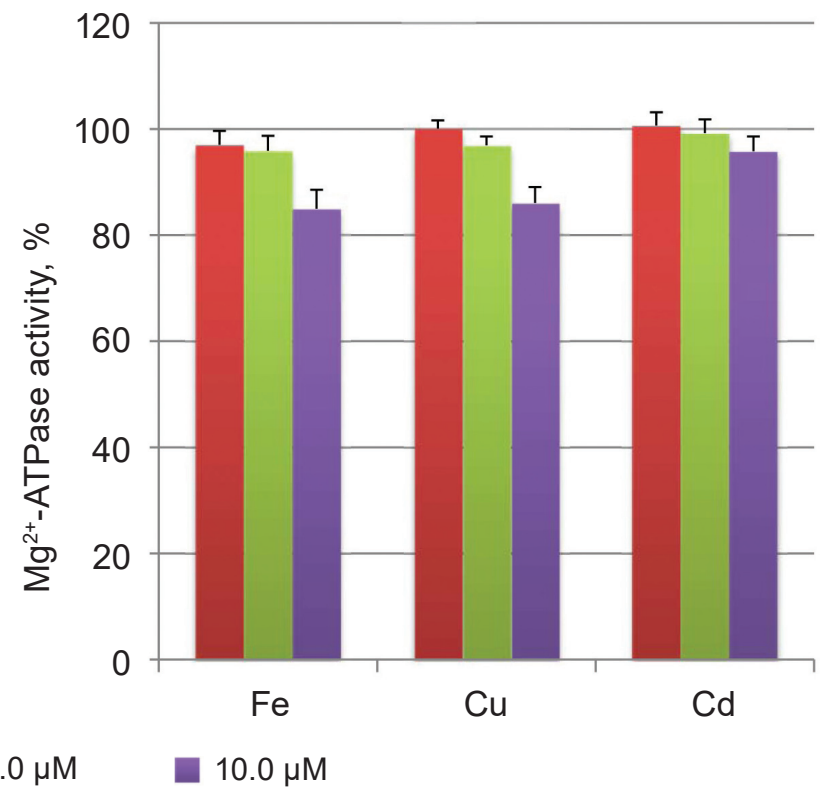

Fig. 1. The influence of the divalent heavy metal ions on the activity of $\mathrm{Na}^{+}, \mathrm{K}^{+}$-ATPase (A) and $\mathrm{Mg}^{2+}$-ATPase (B) of rat CSM ( $M \pm m, n=4-6)$. 100\% - corresponding activity without effector. The concentrations of heavy metals are given in the legend. ${ }^{*}$ Significant differences vs value for $\mathrm{Cu}^{2+}$, ${ }^{*}$ vs corresponding $\mathrm{Mg}^{2+}$-ATPase activity

with $\mathrm{Na}^{+}, \mathrm{K}^{+}$-ATPase may reflect the specifics of the mechanism of ATP hydrolysis by two enzyme systems. These data confirm the specific spermine inhibitory action just on $\mathrm{Na}^{+}, \mathrm{K}^{+}$-ATPase at saturation ion concentrations and may indicate the modulation of the reaction cycle of $\left(\mathrm{Na}^{+}, \mathrm{K}^{+}\right)$-dependent ATPase hydrolytic activity.

Other results indicate, that potent NO-releasing compound sodium nitroprusside (SNP) at concentrations of 0.1-1.0 mM has no effect on $\mathrm{Na}^{+}, \mathrm{K}^{+}$-ATPase activity under standard preincubation conditions of the CSM membranes in ATPase reaction mixture without ATP (for $30 \mathrm{~min}$ ) in the presence of $1 \mathrm{mM}$ EGTA. Chelator addition makes the interference with divalent metal contaminations unlikely. The weak inhibition was revealed only after prolonged pretreatment with $1 \mathrm{mM}$ SNP, enhancing enzyme inactivation by $25 \%$ (Fig. 3). Such inhibitory effect was also revealed for numerous NO-generating compounds in vitro indicating the direct action of $\mathrm{NO}$ on the enzyme through SH-groups oxidation [24]. The formation of the other reactive nitrogen species is uncertain. Despite the mechanism of action and effector groups, such conditions are obviously necessary for nonenzymatic decomposition of the compound. SNP does not affect the $\mathrm{Mg}^{2+}$-ATPase activity. The data correspond to the time course of the $\mathrm{Na}^{+}, \mathrm{K}^{+}$-ATPase inhibition in the cerebral cortex preparations [24], where SH-sensitive isoforms, which are much more susceptible to oxidation, are present [16].

Thus, the $\mathrm{Mg}^{2+}$-ATP-hydrolase in all cases is stable to used agents with different mechanism of

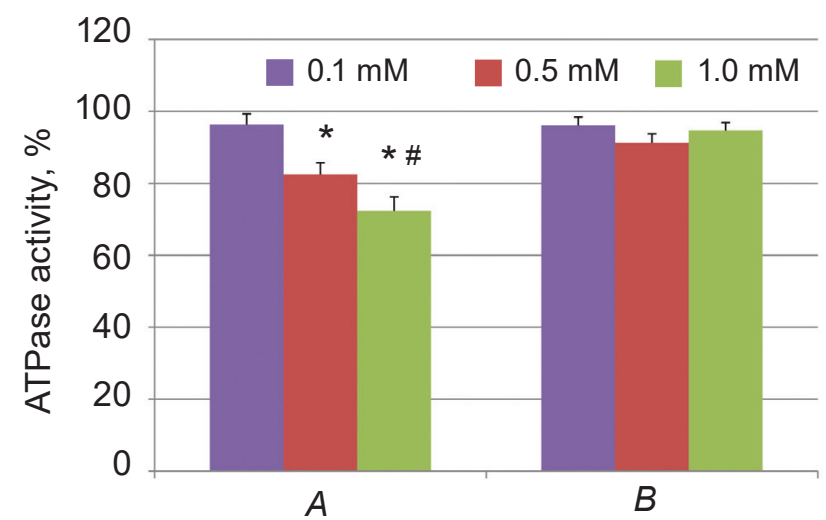

Fig. 2. The influence of the spermine on the activity of $\mathrm{Na}^{+}, \mathrm{K}^{+}$-ATPase (A) and $\mathrm{Mg}^{2+}$-ATPase (B) of rat CSM ( $M \pm m, n=4-5)$. * Significant differences vs control value without spermine, " vs corresponding $\mathrm{Mg}^{2+}$-ATPase activity. 100\% - corresponding activity without effector. Spermine concentrations are given in the legend 


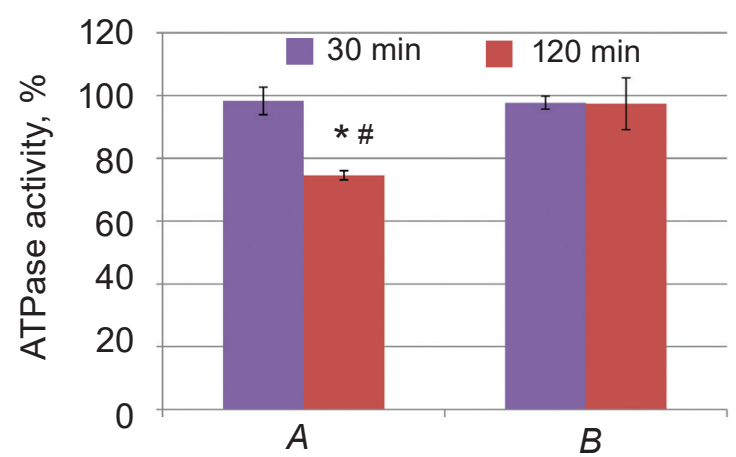

Fig. 3. The influence of the $1 \mathrm{mM}$ sodium nitroprusside (SNP) on the activity of $\mathrm{Na}^{+}, \mathrm{K}^{+}$-ATPase (A) and $M^{2+}$-ATPase (B) of rat CSM $(M \pm m, n=3-4)$.

* Significant differences vs corresponding control without SNP, \# vs corresponding $\mathrm{Mg}^{2+}$-ATPase activity. 100\% - corresponding activity without effector. Preincubation time are given in the legend

action and different effector groups. We demonstrated earlier that $\mathrm{Mg}^{2+}$-ATPase was also more resistant in comparison with $\mathrm{Na}^{+}, \mathrm{K}^{+}$-ATPase to membrane active compounds such as aliphatic alcohols (ethanol), inducing structural membrane disorders $[25,26]$. Taken together, these findings are attributed to the specifics of the membrane structural organization of the active conformation of the mentioned ATPases and indicate their definite ATP-hydrolyzing mechanisms and particular inhibitor action for conformationally labile $\mathrm{Na}^{+}, \mathrm{K}^{+}$-ATPase.

In accordance with previous studies [14], taking into account the high sensitivity of the CSM $\mathrm{Na}^{+}, \mathrm{K}^{+}$-ATPase to inhibition by transition metals and significant increase in the efficiency of the hydrogen peroxide inhibition in the presence of ferrous ions, which is manifested from $\mathrm{H}_{2} \mathrm{O}_{2}$ physiological nanomolar range (under conditions of the Haber-Weiss reaction and generation of the hydroxyl radical as the most potent membrane oxidant [8]), it is suggested that $\mathrm{Na}^{+}, \mathrm{K}^{+}$-ATPase can be a potential effective oxidative target under certain pathophysiological conditions, a marker of oxidative stress and oxidative plasma membrane structural disorders.

These versatile modulators of $\mathrm{Na}^{+}, \mathrm{K}^{+}$-ATPase from other sources with different mode of action enable to further characterize two CSM enzymatic systems that differ by way of ATP hydrolysis [14]. The similarity of the enzymatic properties in smooth muscle and $\mathrm{Na}^{+}, \mathrm{K}^{+}$-ATPase from other tissues revealed by the effect of studied inhibitors should be noted [21-24]. They are determined by the molecu- lar structure and membrane topology, importance of conformational turnover during the catalytic cycle, $\mathrm{SH}$-dependence and sensitivity to lipid environment. Despite also existing tissue-specific individual differences of $\mathrm{Na}^{+}, \mathrm{K}^{+}$-ATPase isozymes in sensitivity to oxidants, SH- and lipid dependence [16], the potential defect of the enzyme in target tissues foremost should be determined by the combined intensity of redox imbalance and antioxidant deficiency and can be expected in conditions of oxidative stress, ischemia, hemochromatosis, iron and copper overloading, heavy metals intoxication.

Evidently, the studies on $\mathrm{Na}^{+}, \mathrm{K}^{+}$-ATPase preparations in vitro do not exactly simulate the complex relationships that exist in the cells under pathophysiological conditions. However, despite the revealed high sensitivity of enzyme to heavy metal ions they indicate tendency of possible processes in vivo and can occur in the cell only in particular conditions of simultaneous hyperproduction of the reactive oxygen or nitrogen species, depletion of the antioxidant defense system and introduction of some sensitizing factors. In addition, it is important to distinguish between reversible regulatory processes under stress conditions to maintain or tune redox homeostasis and adjust redox-dependent signal transduction in the cell and irreversible processes leading to structural and functional disorders and, ultimately, to cell death.

Indeed, numerous studies found functional changes in $\mathrm{Na}^{+}, \mathrm{K}^{+}$-ATPase in the pathogenesis of ischemia and hypoxia in the kidneys and excitable tissues $[27,28]$. It was also shown that during hypoxia, mitochondrial ROS contribute to the inhibition of $\mathrm{Na}^{+}, \mathrm{K}^{+}$-ATPase activity of alveolar epithelial cells by stimulating its endocytosis via PKC-mediated phosphorylation of the $\alpha 1$-subunit of the enzyme $[5,29]$.

In vascular smooth muscle $\mathrm{Na}^{+}, \mathrm{K}^{+}$-ATPase is an important determinant of their tone, mediating the regulation of $\left[\mathrm{Ca}^{2+}\right]_{\mathrm{i}}[3]$. The physiological mechanism of the reversible oxidative regulation of the $\mathrm{Na}^{+}, \mathrm{K}^{+}$-pump in the sarcolemma of the myocardium and vessels is mediated by glutathionylation under oxidative stress of $\beta 1$-subunit cysteine residues in the close vicinity to the site of the association with the $\mathrm{Na}^{+}, \mathrm{K}^{+}$-ATPase $\alpha 1$-subunit that reduces the turnover number of the $\alpha 1 \beta 1$-heterodimer by inducing conformational changes and slowing the rate-limiting conformational transition $\mathrm{E}_{2} \rightarrow \mathrm{E}_{1}$ in a catalytic cycle of $\mathrm{Na}^{+}, \mathrm{K}^{+}$-ATPase pump [7, 30].

In colonic smooth muscles anticipated oxidative defect in the sarcolemma is possible under colon 
pathologies, including colitis, inflammation and erosion of the mucosa with impaired barrier function of the epithelial layer and external smooth muscle exposure to heavy metals and oxidants, nutritional or pharmacological overloading of an organism with iron and copper, hemochromatosis, intoxication with heavy metals. It is obvious that direct defect in $\mathrm{Na}^{+}, \mathrm{K}^{+}$-ATPase may be followed by partial depolarization of the sarcolemma and impairment of the ion homeostasis, including $\left[\mathrm{Ca}^{2+}\right]_{\mathrm{i}}$ via $\mathrm{Na}^{+}, \mathrm{Ca}^{2+}$ exchanger, osmoregulation, electromechanical coupling, large intestine motility.

Hypothetical conditions to ensure a defect at the plasma membrane level require the following: disturbances of the redox homeostasis in the cell, hyperproduction of the reactive oxygen species (superoxide anion radical and hydrogen peroxide) mainly of mitochondrial origin or by plasma membrane NADPH oxidase, depletion of antioxidant defense system, primarily the reduction in the activity of mitochondrial catalase, existence of free labile intracellular iron pool. Hydrogen peroxide is the most stable reactive oxygen compound; it is membrane permeable and acts over long distances in the cell, including plasma membrane [6]. The presence of a labile pool of transition metals (ions of iron or copper) accelerates toxic hydroxyl radical generation.

The question arises about the $\mathrm{Na}^{+}, \mathrm{K}^{+}$-ATPase involvement in the mechanisms of cell death and induced cytotoxicity in the context of deregulation of redox homeostasis in the cell. It is known that in some malignant neoplasms $\mathrm{Na}^{+}, \mathrm{K}^{+}$-ATPase inhibition by cardiac glycosides, accompanied with the increase in $\left[\mathrm{Na}^{+}\right]_{\mathrm{i}}$, concomitant $\left[\mathrm{Ca}^{2+}\right]_{\mathrm{i}}$ increase and $\left[\mathrm{K}^{+}\right]_{\mathrm{i}}$ depletion, leads to apoptosis [31]. In cultures of vascular smooth muscle, endothelial cells and astrocytes the cytotoxic action of ouabain $(3 \mu \mathrm{M})$, developed in 24 hours period, is shown only for human cells, but this cardiac steroid did not affect cell viability of rat cells (at concentrations up to $5 \mathrm{mM}$ ). However, the same complete inhibition of $\mathrm{Na}^{+} \mathrm{K}^{+}$-ATPase, accompanied by dramatic increase of $\left[\mathrm{Na}^{+}\right]_{\mathrm{i}} /\left[\mathrm{K}^{+}\right]_{\mathrm{i}}$, occurred. Certainly, it is a result of the species-dependent differences in the unique receptor properties of the ouabain-sensitive and rodent ouabain-resistant $\mathrm{Na}^{+}, \mathrm{K}^{+}$-ATPase catalytic subunit $\alpha 1$-isoform, rather than in features of the signaling mechanisms of cell death [32].

Recently, it was established that $\mathrm{Na}^{+}, \mathrm{K}^{+}$-ATPase plays a crucial role in the regulation of autosis development - new morphologically unique type of autophagy-dependent cell death occurring under autophagy, triggered by certain peptides and stress conditions of starvation, ischemia-hypoxia of the brain in both in vitro and in vivo. Blockers of apoptosis and necrosis do not affect the autosis development, which, however, is inhibited by cardiac glycosides - pharmacological $\mathrm{Na}^{+}, \mathrm{K}^{+}$-ATPase antagonists, pharmacological and genetic autophagy blockers and genetic knockdown of the $\mathrm{Na}^{+}, \mathrm{K}^{+}$-ATPase $\alpha 1$-subunit [33].

On the model of smooth muscle pathology of pulmonary arterial hypertension in rats it was shown that the acceleration of oxidative phosphorylation by sodium dichloroacetate (SDA) - the inhibitor of pyruvate dehydrogenase kinase, which expression is increased in this pathology, was accompanied by increased generation of mitochondrial ROS, namely $\mathrm{H}_{2} \mathrm{O}_{2}$, capable to diffuse into the cytoplasm promoting intracellular effects, including opening and activation of sarcolemmal voltage-gated $\mathrm{K}^{+}$channels, associated vasodilation, hypertension reversal, ultimately inducing mitochondrial-dependent apoptosis [34]. Obviously, the differences in the expression of respiratory chain enzymes, Mn-superoxide dismutase and, actually, the efficiency of $\mathrm{H}_{2} \mathrm{O}_{2}$ production in mitochondria, that affects smooth muscle cell membrane potential and cytosolic calcium, may determine the opposite response to hypoxia of pulmonary and renal arteries, causing their constriction or dilation, respectively [35]. A similar mechanism of SDA action, increasing mitochondrial metabolism and ROS production under mitochondrial dysfunction is specific for many malignant tumors, which energy metabolism, as known, is characterized by the Warburg effect against the background of the mitochondrial structure-functional disorders [6]. In our previous studies, the cytotoxic action of SDA was observed only in transplanted sarcoma 37, but not in Lewis lung carcinoma, as a possible result of the biological properties of tumors, characteristics and extent of energy metabolism reprogramming, structural and functional abnormalities of the mitochondrial membranes and prooxidant-antioxidant homeostasis impairment $[6,36,37]$.

Our researches have found a continuation in further investigations. It was shown that exogenous ascorbate is able to induce necrosis and apoptosis in the cells of many tumors treated with SDA without loading with exogenous iron preparations, but due to involvement of the intracellular free labile iron pool. It specifically increased in tumors and catalyzed 
Haber-Weiss reaction and generation of hydroxyl radicals [38]. The contribution of the $\mathrm{Na}^{+}, \mathrm{K}^{+}$-ATPase defect in induced cytotoxicity as a sensor or a target of the oxidative-mediated damage of the plasma membrane is not excluded under these conditions.

Thus, this study shows that $\mathrm{CSM} \mathrm{Na} \mathrm{Na}^{+}, \mathrm{K}^{+}$ ATPase is highly sensitive to heavy metals and is also inhibited by polyamine spermine as modulator of conformational turnover and SNP as nitric oxide donor. Taking into account the available scientific evidences, presented data and previous studies on $\mathrm{Na}^{+}, \mathrm{K}^{+}$-ATPase specific sensitivity to heavy metals and prooxidants and enzyme inhibitory lability in CSM [14] it is suggested that this enzyme system is characterized by biochemical features that allow it to be a potential target and redox sensor mediating pathophysiological mechanisms of intoxication by heavy metals and oxidative cell damage in different tissues.

\section{ВПЛИВ ІОНІВ ВАЖКИХ МЕТАЛІВ, СПЕРМІНУ ТА НІТРОПРУСИДУ НАТРІЮ НА АТР-ГІДРОЛАЗИ КЛІТИННИХ МЕМБРАН ГЛАДЕНЬКИХ М'ЯЗІВ ОБОДОВОЇ КИШКИ ЩУРА}

\section{О. А. Капля}

Інститут біохімії ім. О. В. Палладіна НАН України, Київ; e-mail: kaplya@biochem.kiev.ua

Досліджено особливості функціональної лабільності АТР-гідролаз клітинних мембран гладеньких м'язів ободової кишки (ГМОК). Показано, що $\mathrm{Na}^{+}, \mathrm{K}^{+}$-АТРаза ефективно інгібується двовалентними іонами як перехідних ( $\geq 0,1$ мкM), так і неперехідних ( $\geq 1$ мкM) важких металів у послідовності за ефективністю: $\mathrm{Cu}^{2+}>\mathrm{Fe}^{2+} \geq \mathrm{Cd}^{2+}(10$ мкM). Поліамін спермін $\left(0,5-1,0\right.$ мМ) - слабкий інгібітор $\mathrm{Na}^{+}, \mathrm{K}^{+}$-АТРази ГМОК за насичуючих концентрацій іонів i субстрату. Донор оксиду азоту нітропрусид натрію (1 мМ) виявляв слабкий інгібувальний ефект на $\mathrm{Na}^{+}, \mathrm{K}^{+}$-АТРазу тільки за довготривалої попередньої інкубації 3 мембранами. $\mathrm{Mg}^{2+}$ АТРаза у всіх випадках була значно стійкішою до дії досліджуваних агентів. На прикладі $\mathrm{Na}^{+}, \mathrm{K}^{+}$-АТРази ГМОК припускається, що ензим характеризується біохімічними особливостями, які забезпечують можливість бути потенційною мішенню та редокс-сенсором, що опосередковує патофізіологічні механізми інтоксикації важкими металами та оксидативного ушкодження клітин.

К л ю ч о в і с л о в а: АТР-гідролази, $\mathrm{Na}^{+}, \mathrm{K}^{+}$АТРаза, гладенькі м'язи ободової кишки, важкі метали, спермін, нітропрусид натрію.

\section{ВЛИЯНИЕ ИОНОВ ТЯЖЕЛЫХ МЕТАЛЛОВ, СПЕРМИНА И НИТРОПРУССИДА НАТРИЯ НА АТР-ГИДРОЛАЗЫ КЛЕТОЧНЫХ МЕМБРАН ГЛАДКИХ МЫШЦ ОБОДОЧНОЙ КИШКИ КРЫСЫ}

\section{A. А. Капля}

Институт биохимии им. А. В. Палладина НАН Украины, Киев; e-mail: kaplya@biochem.kiev.ua

Исследованы особенности функциональной лабильности АТР-гидролаз клеточных мембран гладких мышц ободочной кишки (ГМОК). Показано, что $\mathrm{Na}^{+}, \mathrm{K}^{+}$-АТРаза эффективно ингибируется двухвалентными ионами как переходных ( $\geq 0,1$ мкM), так и непереходных ( $\geq 1$ мкM) тяжелых металлов в последовательности по эффективности: $\mathrm{Cu}^{2+}>\mathrm{Fe}^{2+} \geq \mathrm{Cd}^{2+}(10$ мкM). Полиамин спермин $(0,5-1,0$ мМ) - слабый ингибитор $\mathrm{Na}^{+}, \mathrm{K}^{+}$-АТРазы ГМОК при насыщающих концентрациях ионов и субстрата. Донор оксида азота нитропруссид натрия (1 мМ) проявлял слабый ингибирующий эффект на $\mathrm{Na}^{+}, \mathrm{K}^{+}$-АТРазу только при долговременной инкубации с мембранами. $\mathrm{Mg}^{2+}$-АТРаза во всех случаях была значительно более устойчива к действию исследованных агентов. На примере $\mathrm{Na}^{+}, \mathrm{K}^{+}$-АТРазы ГМОК предполагается, что энзим характеризуется биохимическими особенностями, позволяющими выступать потенциальной мишенью и редокссенсором, опосредующим патофизиологические механизмы интоксикации тяжелыми металлами и оксидативного повреждения клеток.

Ключевы е сллов а: АТР-гидролазы, $\mathrm{Na}^{+}, \mathrm{K}^{+}$-АТРаза, гладкие мышцы ободочной кишки, тяжелые металлы, спермин, нитропруссид натрия. 


\section{References}

1. Glitsch HG. Electrophysiology of the sodiumpotassium-ATPase in cardiac cells. Physiol Rev. 2001; 81(4): 1791-1826.

2. Kosterin SA. Calcium transport in smooth muscle. Kiev:Naukova Dumka,1990. 216 p. (In Russian).

3. Ishida Y, Paul RJ. $\mathrm{Ca}^{2+}$ clearance in smooth muscle: lessons from gene-altered mice. J Smooth Muscle Res. 2005; 41(5): 235-245.

4. Michiels C. Physiological and pathological responses to hypoxia. Am J Pathol. 2004 Jun;164(6):1875-1882.

5. Hamanaka RB, Chandel NS. Mitochondrial reactive oxygen species regulate cellular signaling and dictate biological outcomes. Trends Biochem Sci. 2010; 35(9): 505-513.

6. Kaplia AA, Sorokina LV, Khyzhnyak SV. Reprogramming of mitochondrial energy metabolism in malignant neoplasms. $U k r$ Biochem J. 2015; 87(6): 19-35. (In Russian).

7. Figtree GA, Liu CC, Bibert S, Hamilton EJ, Garcia A, White CN, Chia KK, Cornelius F, Geering K, Rasmussen HH. Reversible oxidative modification: a key mechanism of $\mathrm{Na}^{+}-\mathrm{K}^{+}$pump regulation. Circ Res. 2009; 105(2): 185-193.

8. Baraboy VA. Bioantioxidants. Kiev: Kniga plyus, 2006. 462 p. (In Russian).

9. Britton RS, Leicester KL, Bacon BR. Iron toxicity and chelation therapy. Int $J$ Hematol. 2002; 76(3): 219-228.

10. Brissot P, Ropert M, Le Lan C, Loréal O. Nontransferrin bound iron: a key role in iron overload and iron toxicity. Biochim Biophys Acta. 2012; 1820(3): 403-410.

11. Vasic VM, Colovic MB, Krstić DZ. Mechanism of $\mathrm{Na}^{+}, \mathrm{K}^{+}$-ATPase and $\mathrm{Mg}^{2+}$-ATPase inhibition by metal ions and complexes. Hem Ind. 2009; 63(5a): 499-509.

12. Khyzhnyak SV. Cellular mechanisms of cadmium toxicity. Kyiv: Lat\&K, 2010. 213 p. (In Ukrainian).

13. Kaplia AA. The heterogeneity of the $\mathrm{Na}^{+}, \mathrm{K}^{+}-$ ATPase ouabain sensitivity in microsomal membranes of rat colon smooth muscles. $U k r$ Biokhim Zhurn. 2011; 83(5): 89-93. (In Russian).

14. Kaplia AA. The influence of iron ions on ATPhydrolases activity of cell membranes of rat colon smooth muscle and kidney. Ukr Biochem J. 2015; 87(1): 83-90. (In Ukrainian).
15. Chen PS, Toribara TY, Warner H. Microdetermination of phosphorus. Anal Chem. 1956; 28(11): 1756-1758.

16. Kaplia AA. Structural organization and functional role of $\mathrm{Na}^{+}, \mathrm{K}^{+}$-ATP-ase isozymes. Kiev: Kiev University Press, 1998. 162 p. (In Russian).

17. Goldshleger R, Bar Shimon M, Or E, Karlish SJ. Metal-catalysed cleavage of Na,K-ATPase as a tool for study of structure-function relations. Acta Physiol Scand Suppl. 1998; 643: 89-97.

18. Shimon MB, Goldshleger R, Karlish SJ. Specific $\mathrm{Cu}^{2+}$-catalyzed oxidative cleavage of $\mathrm{Na}, \mathrm{K}-$ ATPase at the extracellular surface. J Biol Chem. 1998; 273(51): 34190-34195.

19. Goldshleger R, Patchornik G, Shimon MB, Tal DM, Post RL, Karlish SJ. Structural organization and energy transduction mechanism of $\mathrm{Na}^{+}, \mathrm{K}^{+}$-ATPase studied with transition metal-catalyzed oxidative cleavage. J Bioenerg Biomembr. 2001; 33(5): 387-399.

20. Patchornik G, Munson K, Goldshleger R, Shainskaya A, Sachs G, Karlish SJ. The ATP$\mathrm{Mg}^{2+}$ binding site and cytoplasmic domain interactions of $\mathrm{Na}^{+}, \mathrm{K}^{+}$-ATPase investigated with $\mathrm{Fe}^{2+}$-catalyzed oxidative cleavage and molecular modeling. Biochemistry. 2002; 41(39): 1174011749.

21. Krstić D, Krinulović K, Vasić V. Inhibition of $\mathrm{Na}(+) / \mathrm{K}(+)$-ATPase and $\mathrm{Mg}(2+)$-ATPase by metal ions and prevention and recovery of inhibited activities by chelators. $J$ Enzyme Inhib Med Chem. 2005; 20(5): 469-476.

22. Tashima Y, Hasegawa M, Lane LK, Schwartz A. Specific effects of spermine on $\mathrm{Na}^{+}, \mathrm{K}^{+}$-adenosine triphosphatase. J Biochem. 1981; 89(1): 249-255.

23. Garçon DP, Lucena MN, França JL, McNamara JC, Fontes CF, Leone FA. $\mathrm{Na}^{+}, \mathrm{K}^{+}-$ ATPase activity in the posterior gills of the blue crab, Callinectes ornatus (Decapoda, Brachyura): modulation of ATP hydrolysis by the biogenic amines spermidine and spermine. J Membr Biol. 2011; 244(1): 9-20.

24. Sato $T$, Kamata $Y$, Irifune $M$, Nishikawa $T$. Inhibitory effect of several nitric oxidegenerating compounds on purified $\mathrm{Na}(+), \mathrm{K}(+)$ ATPase activity from porcine cerebral cortex. J Neurochem. 1997; 68(3): 1312-1318.

25. Mishchuk DO, Zimina VP, Kaplia AA. Ethanol sensitivity of rat brain cortex $\mathrm{Na}^{+}, \mathrm{K}^{+}$-ATPase in plasma membrane structural damage induced 
by sodium dodecyl sulfate. Ukr Biokhim Zhurn. 2002; 74(5): 55-61. (In Russian).

26. Mishchuk DO, Kaplia AA. Effect of ethanol on structural and functional characteristics of rat brain cortical membranes in vitro. Ukr Biokhim Zhurn. 2003; 75(2): 55-61. (In Russian).

27. Kaplia AA, Mishchuk DO. $\mathrm{Na}^{+}, \mathrm{K}^{+}$-ATPase isoenzymes of excitable tissues in pathological states. Ukr Biokhim Zhurn. 2001; 73(5): 17-22. (In Russian).

28. Kaplia AA, Morozova VS. $\mathrm{Na}^{+}, \mathrm{K}^{+}$-ATPase activity in polarized cells. Ukr Biokhim Zhurn. 2010; 82(1): 5-20. (In Russian).

29. Dada LA, Chandel NS, Ridge KM, Pedemonte C, Bertorello AM, Sznajder JI. Hypoxia-induced endocytosis of Na,K-ATPase in alveolar epithelial cells is mediated by mitochondrial reactive oxygen species and PKC-zeta. $J$ Clin Invest. 2003; 111(7): 1057-1064.

30. Liu CC, Karimi Galougahi K, Weisbrod RM, Hansen T, Ravaie R, Nunez A, Liu YB, Fry N, Garcia A, Hamilton EJ, Sweadner KJ, Cohen RA, Figtree GA. Oxidative inhibition of the vascular $\mathrm{Na}^{+}-\mathrm{K}^{+}$pump via NADPH oxidase-dependent $\beta 1$-subunit glutathionylation: implications for angiotensin II-induced vascular dysfunction. Free Radic Biol Med. 2013; 65: 563-572.

31. Kaplia AA, Khizhniak SV, Kudriavtseva AG, Papageorgakopulu N, Osinskiı̌ DS. $\mathrm{Na}^{+}, \mathrm{K}^{+}-$ ATPase and $\mathrm{Ca}^{2+}$-ATPase isozymes in malignant neoplasms. Ukr Biokhim Zhurn. 2006; 78(1): 2942. (In Russian).

32. Akimova OA, Tverskoi AM, Smolyaninova LV, Mongin AA, Lopina OD, La J, Dulin NO, Orlov SN. Critical role of the $\alpha 1-\mathrm{Na}(+), \mathrm{K}(+)-$ ATPase subunit in insensitivity of rodent cells to cytotoxic action of ouabain. Apoptosis. 2015; 20(9): 1200-1210.
33. Liu Y, Shoji-Kawata S, Sumpter RM Jr, Wei Y, Ginet V, Zhang L, Posner B, Tran KA, Green DR, Xavier RJ, Shaw SY, Clarke PG, Puyal $\mathrm{J}$, Levine B. Autosis is a $\mathrm{Na}^{+}, \mathrm{K}^{+}$-ATPaseregulated form of cell death triggered by autophagy-inducing peptides, starvation, and hypoxia-ischemia. Proc Natl Acad Sci USA. 2013; 110(51): 20364-20371.

34. McMurtry MS, Bonnet S, Wu X, Dyck JR, Haromy A, Hashimoto K, Michelakis ED. Dichloroacetate prevents and reverses pulmonary hypertension by inducing pulmonary artery smooth muscle cell apoptosis. Circ Res. 2004; 95(8): 830-840.

35. Michelakis ED, Hampl V, Nsair A, Wu X, Harry G, Haromy A, Gurtu R, Archer SL. Diversity in mitochondrial function explains differences in vascular oxygen sensing. Circ Res. 2002; 90(12): 1307-1315.

36. Sorokina LV, Pyatchanina TV, Didenko GV, Kaplia AA, Khyzhnyak SV. The influence of sodium dichloroacetate on the oxidative processes in sarcoma 37. Exp Oncol. 2011; 33(4): 216-221.

37. Khyzhnyak SV, Sorokina LV, Stepanova LI, Kaplia AA. Functional and dynamic state of inner mitochondrial membrane of sarcoma 37 in mice under administration of sodium dichloroacetate. Ukr Biochem J. 2014; 86(6): 106-118.

38. McCarty MF, Contreras F. Increasing Superoxide Production and the Labile Iron Pool in Tumor Cells may Sensitize Them to Extracellular Ascorbate. Front Oncol. 2014; 4: 249.

Received 02.03.2016 